\title{
SYSTEM OF FINANCING HEALTH CARE IN THE EUROPEAN UNION COUNTRIES AS AN EXPERIENCE FOR UKRAINE
}

\author{
Olha Lisovska'
}

\begin{abstract}
Purpose. The purpose of the article is to analyse the state of the system of financing health care in the European Union countries and Ukraine, to identify and compare their efficiency. To achieve this purpose, the following tasks were set: to analyse the current state of the system of financing health care in the European Union using up-to-date statistics on health care expenditures; to analyse the state of the system of financing health care in Ukraine for the last five years based on statistical data on expenditures of the Consolidated Budget of Ukraine; to consider what needs the health care sector directs expenditures to; to identify the problems that were prompted medical reform in Ukraine; to identify and compare the efficiency of financing the health care system of the European Union countries and Ukraine. Methodology. During the preparation of the article, the author used the method of analysis and synthesis to review statistical data that provided an opportunity to analyse the current state of the system of financing health care in the European Union countries and Ukraine; the method of comparison was used to determine the efficiency of the models of the system of financing health care in the countries of the European Union, in order to further form useful advice for use in Ukraine during the period of medical reform; generalization method was used to summarize the results of the study. Results. Analysing the state of the system of financing health care among the European Union countries in 2019, it was found that the largest amount of health care expenditures was in Germany (the system of financing was based on the Bismarck model), and the smallest was in Latvia (the system of financing was based on the Beveridge model). Analysis of the dynamics of health care expenditures in Ukraine showed that over the past five years, the volume of expenditures has increased 2.33 times. In terms of the funds of the Consolidated Budget of Ukraine, the largest percentage (85-91\%) falls on the expenditures of the general fund. In relation to the total expenditures of the Consolidated Budget of Ukraine, the share of health care expenditures in 2020 has amounted to $11.02 \%$, which is 1.99\% higher than in 2016 . Despite the growing trend, the amount of budget expenditures is not enough for all the needs of the health sector. To identify the efficiency of the models of the systems of financing health care operating in the European Union countries and Ukraine, a comparison of the average life expectancy among the people of these countries was made. In the countries of Northern and Western Europe, there was the highest rate in the range of 81.1-83.1 years for both men and women; the lowest rate was observed in Ukraine (73 years). Ukraine is currently undergoing health care reform, which should change the Soviet model to one that will be closer to the English, which shows its efficiency on the example of European countries in the post-Soviet space. Practical implications. The results of the study can be used to form practical suggestions in preparation for the next stage of health care reform in Ukraine.
\end{abstract}

Key words: health insurance, health care system, health care models, health care expenditure, European Union, Ukraine.

JEL Classification: G22, G28, G32, 113

\section{Introduction}

The health of citizens has a significant impact on the economic development of the country, which directly depends on the state of financing health care. The system of financing health care, which has continued

Corresponding author:

${ }^{1}$ University of the State Fiscal Service of Ukraine, Ukraine.

E-mail: olya.lisovskaya94@gmail.com

ORCID: https://orcid.org/0000-0002-2842-3158

ResearcherID: ABE-7161-2020 to operate in Ukraine after the collapse of the Soviet Union, has proven efficiency over the years. After all, due to insufficient funds to finance the industry, the right of citizens to free health care, medical assistance and health insurance, guaranteed by the Constitution 
of Ukraine, was not realized. It should be noted that during the period from the declaration of independence in 1991 until the adoption of the Concept of Health Care Financing Reform in 2016, there was no significant reform in the field of health care in Ukraine.

In accordance with the Concept and a number of adopted regulations, since 2018 Ukraine has started health care reform, which aims to introduce compulsory health insurance, in which the state acts as an insurer, and funding is based on the principle of "money follows the patient". The implementation of the reform is provided in three stages and, according to the Concept, it should be completed in 2020, but the COVID-19 pandemic has changed the plans, thus extending the implementation of health care reform in the coming years. In the period of transformation of the domestic healthcare sector and the formation of an efficient system of financing it, it will be useful to use the experience of developed countries.

\section{Analysis of the current state of financing health care in the European Union countries}

In the countries of the European Union, health care systems are based on the Bismarck Model and the Beveridge Model. The Bismarck Model, also known as German model, is compulsory social health insurance for working peoples and their families. Contributions are paid to private insurance funds in the way that one part is paid by employers as targeted contributions and the other part is paid independently by employees. This model is used in Austria, Belgium, Italy, Estonia, Lithuania, Luxembourg, the Netherlands, Germany, Poland, Slovakia, Slovenia, Hungary, France, Sweden, the Czech Republic etc.

The Beveridge Model, also known as English model, means the universal coverage of medical services for all citizens at the expense of taxes paid to the budget. The state acts as a monopolist insurer with the authority to plan expenditures in the formation of the state budget and control their use. This model is used in Denmark, Ireland, Spain, Latvia, Portugal, Finland etc. (Kulesher, Forrestal, 2014; Wielechowski, Grzęda, 2020).

Let us analyse the amount of health care expenditures per capita in some countries of the European Union for 2019, the structure of which consists of:

- government / compulsory schemes;

- voluntary health care payment schemes;

- household out-of-pocket payments.

Figure 1 shows that the largest amount of health care expenditures is in Germany (6645.8 USD per capita), Austria (5851.1 USD per capita) and Sweden (5782.3 USD per capita), and the lowest is in Hungary (2222.4 USD per capita), Poland (2229.6 USD per capita) and Latvia (1972.6 USD per capita).

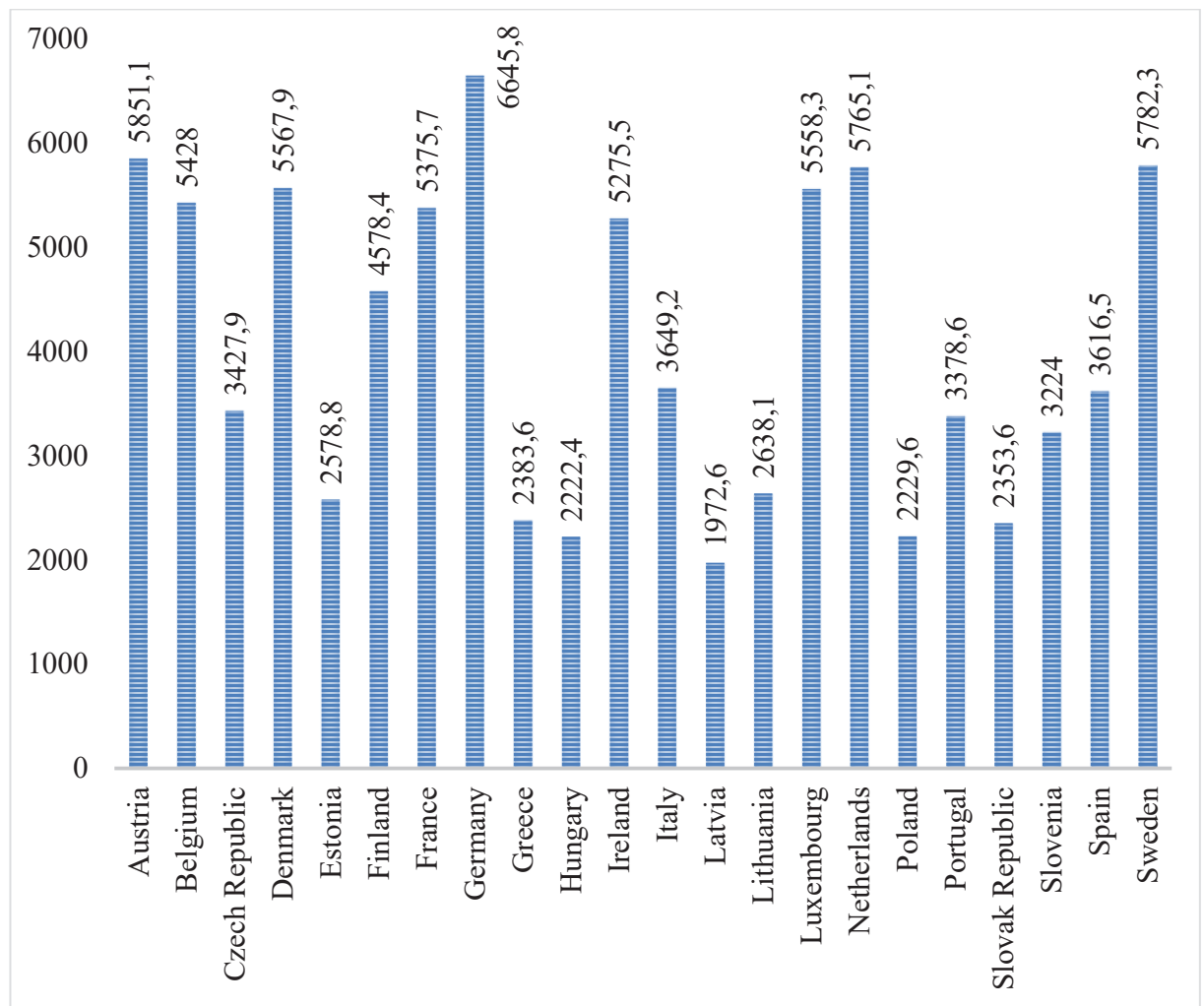

Figure 1. Health care expenditure per capita in the European Union countries in 2019, USD

Source: compiled by the author based on OECD statistics 
This is due to economic differences between the countries of Northern and Western Europe, and the countries of Central and Eastern Europe, in terms of GDP, GNP, level of social security, wages, life expectancy etc. The average annual growth rate of health care expenditures per capita in 2019, compared to 2018 , had a growing trend in all countries of the European Union (OECD/EU, 2020).

\section{Analysis of the condition of financing health system care in Ukraine}

After the collapse of the USSR, Ukraine inherited a health care system based on the Semashko Model, i.e. financing health care from the state budget, at the expense of which citizens were provided with free medical care (Onyshko, Shevchuk, 2019).

According to the budget classification, the expenditures of the Consolidated Budget of Ukraine for health care are directed to:

a) polyclinics and outpatient clinics, emergency medical services:

- general polyclinics and outpatient clinics;

- specialized clinics and dental care clinics;

- emergency medical care centres and medical centres

for disasters, ambulance stations;

- medical and obstetrical stations;

- primary medical centres;

b) hospitals and sanatoriums:

- general hospitals;

- specialized hospitals and other specialized facilities;

- perinatal centres, maternity hospitals;

- sanatoriums;

c) sanitation and anti-epidemic measures and facilities; d) basic and applied health care research and development;

e) other health care activities:

- orphanages;

- blood transfusion centres;

- other facilities and activities in the field of health care (The Official website of The State Treasury Service of Ukraine, 2021).

Let us analyse the dynamics of health care expenditures of the Consolidated Budget of Ukraine over the past five years. Figure 2 shows that the largest share falls on the general fund, which in percentage terms is $85 \%, 85 \%, 86 \%, 89 \%$, and $91 \%$ for 2016 , $2017,2018,2019$, and 2020, respectively, and the expenditures of the special fund are $15 \%, 15 \%, 14 \%$, $11 \%$, and $9 \%$ for $2016,2017,2018,2019$, and 2020, respectively. In comparison to 2016, in 2020 the volume of health care expenditures increased by 100.2 billion UAH (2.33 times).

The share of health care expenditures in relation to the total amount of expenditures of the Consolidated Budget of Ukraine amounted to $9.03 \%$ (2016), 9.69\% (2017), 9.27\% (2018), 9.36\% (2019), $11.02 \%$ (2020) (Zvitnist, 2021). Although in 2020 the volume of health care expenditures has increased, but still this amount of expenditure is not enough to meet all the needs of the health care sector, so there is a need to find additional sources of income.

\section{Efficiency of the systems of financing health care in the European Union countries and Ukraine}

Inefficient allocation of budget funds for health care leads to a number of problems, namely:

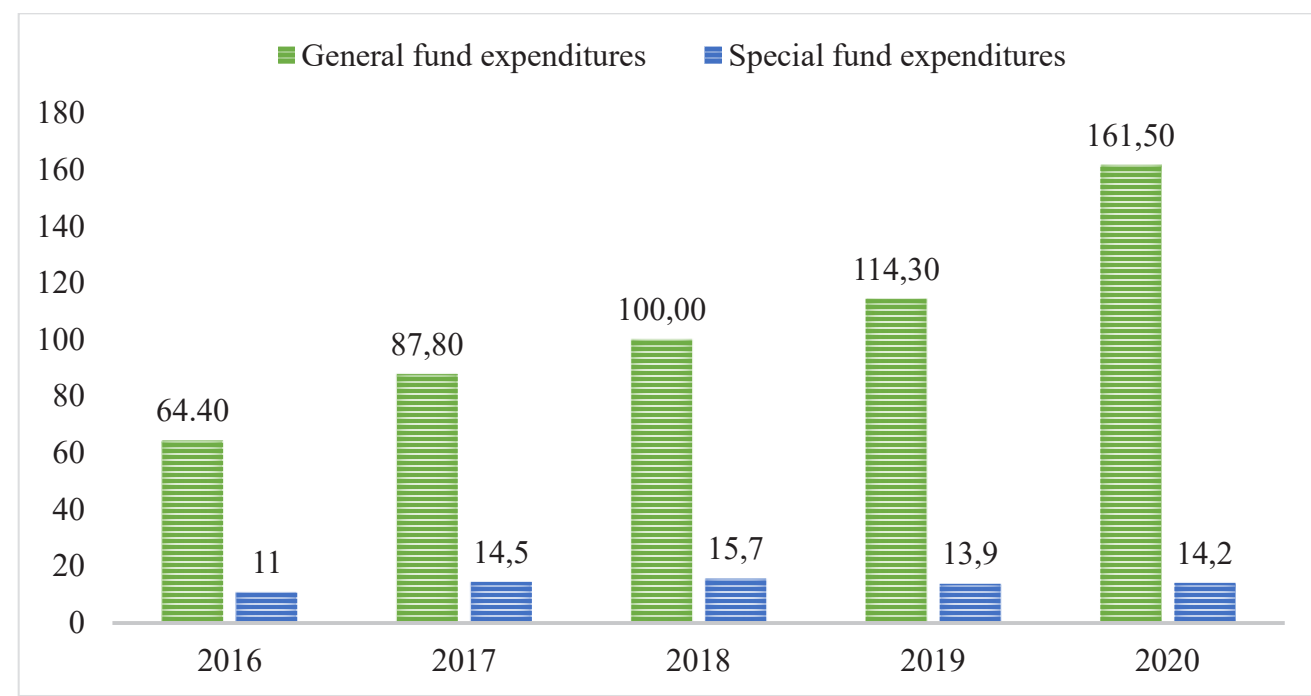

Figure 2. Dynamics of health care expenditures of the Consolidated Budget of Ukraine for 2016-2020, billion UAH

Source: compiled by the author based on the statistics of the State Treasury Service of Ukraine 
- low coverage of the population with free medical services and, as a consequence, an increase in out-ofpocket payments;

- inequality in access to health care;

- low quality of medical services;

- reduction in qualification and number of medical personnel working in state medical facilities;

- increase in mortality due to preventive medicine is not available for the population, etc. (Apetroi et al., 2020).

The experience of the European Union countries confirms the efficiency of their systems of financing health care, although there is no universal system of financing health care in the world that would suit absolutely all countries. For example, in the period after the collapse of the Soviet Union and until 2015, the mortality rate in Ukraine increased by $8 \%$, while in the post-Soviet European countries this figure decreased by $42 \%$.

These problems prompted the Ukrainian authorities in 2016 to approve the Concept of Health Care Financing Reform and to begin health care reform in 2018, which aimed to change the Soviet model of financing health care to a more efficient one, which would be as similar as possible to the Beveridge Model, and to introduce compulsory health insurance (Romaniuk, Semigina, 2018).
The efficiency of the system of financing health care in the country can be seen from the indicator of life expectancy. Figure 3 shows that the highest life expectancy is in the countries of Northern and Western Europe, where the system of financing health care is based on the Bismarck Model. In the post-Soviet countries, which are currently members of the European Union, the average life expectancy is only 3-5 years higher than in Ukraine, although these countries have implemented their health care reforms much earlier.

In comparison to all countries of the European Union, the lowest life expectancy in Ukraine was 73 years in 2019 (for both sexes). In 2015, this figure was 72.2 years (WHO, 2020). This may indicate that the first stage of health reform has shown a small but positive trend.

\section{Conclusion}

In accordance with the purpose and objectives of the study, we can conclude that the analysis of health expenditures and life expectancy has confirmed that the most efficient systems of financing health care are those of Northern and Western European countries. The inefficient allocation of funds from the state budget, which was based on the Soviet model, led to a number of problems in the field of health care in Ukraine, which confirmed the inefficiency of this model. The

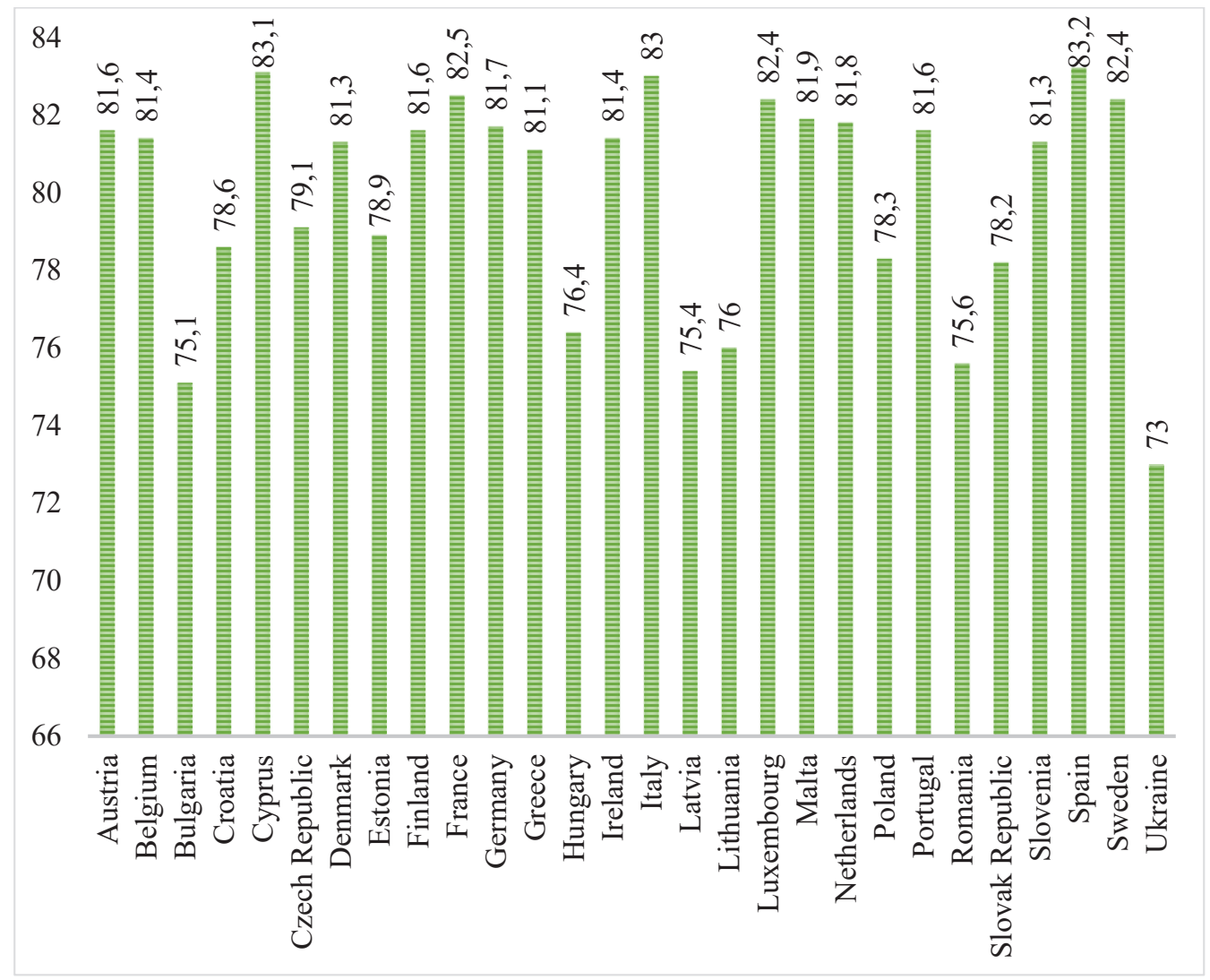

Figure 3. The average life expectancy in 2019 in the European Union countries and Ukraine, years

Source: compiled by the author based on WHO data 
health care reform launched in 2018 aims to change the model of financing health care to one based on the Beveridge Model and to introduce compulsory health insurance, which is theoretically prescribed in the Law of Ukraine "On Insurance" from 1996; however, it does not exist to this day. The experience of the European
Union, especially the post-Soviet countries, is useful and convincing for Ukraine during the period of transformation of its health care sector.

As the process of medical reform is underway in Ukraine, this topic remains relevant for further research.

\section{References:}

Apetroi (Răcoare), F.-C., Michalanche, I.-C., Tomaziu-Todosia, M., \& Plotnic, O. (2020). An economic approach to health insurance. Logos Universality Mentality Education Novelty: Social Sciences, vol. 9, issue 1, pp. 1-13. doi: https://doi.org/10.18662/lumenss/9.1/31

Kulesher, R., \& Forrestal, E. (2014). International models of health systems financing. Journal of Hospital Administration, vol. 3, no. 4, pp. 127-139. doi: 10.5430/jha.v3n4p127

OECD.Stat (2021). Official website of The Organisation for Economic Co-operation and Development. Retrieved from: https://stats.oecd.org/Index.aspx?ThemeTreeId=9 (accessed April 16, 2021).

Onyshko, S., \& Shevchuk, Y. (2019). Functioning specifics of medical insurance financial support models. Economic Herald. Series: Finance, Accounting, Taxation, no. 3, pp. 171-179. doi: https://doi.org/10.33244/26175932.3.2019.171-179

Organisation for Economic Co-operation and Development, \& European Union (OECD/EU) (2020). Health at a Glance: Europe 2020. State of Health in the EU Cycle, $230 \mathrm{p}$. Official website of The OECD iLibrary. Retrieved from: https://www.oecd-ilibrary.org/social-issues-migration-health/health-at-a-glance-europe-2020 82129230-en (accessed April 15, 2021). doi: https://doi.org/10.1787/82129230-en

Romaniuk, P., \& Semigina, T. (2018). Ukrainian health care system and its chances for successful transition from Soviet legacies. Globalization and Health, no. 14:116, pp. 1-11. doi: https://doi.org/10.1186/s12992-018-0439-5 Wielechowski, M., \& Grzęda, Ł. (2020). Health care financing in the European Union countries - structure and changes. Acta Scientiarum Polonorum Oeconomia, no. 19(1), pp. 71-80. doi: 10.22630/ASPE.2020.19.1.8

World Health Organization (2020). Life expectancy and Healthy life expectancy. Data by country. Official website of The WHO. Retrieved from: https://apps.who.int/gho/data/node.main.688 (accessed April 16, 2021).

Zvitnist [Accounting] (2021). Ofitsiinyi sait Derzhavnoi kaznacheiskoi sluzhby Ukrainy [Official website of The State Treasury Service of Ukraine]. Retrieved from: https://www.treasury.gov.ua/ua/file-storage/vikonannyaderzhavnogo-byudzhetu (accessed April 15, 2021). 